\title{
Traumatic corneal flap displacement after laser in situ keratomileusis (LASIK) [Erratum]
}

\author{
Tsai TH, Peng KL, Lin CJ. International Medical Case \\ Reports Journal. 2017;10:143-148
}

On page 144, right column, last paragraph, "Informed consent was obtained from the patient for publication of this case report and accompanying images. The ethics committee of ....... did not require written informed consent be obtained from the patient because ....." should have read "Written informed consent was obtained from the patient for publication of this Case Report and accompanying images".

The International Medical Case Reports Journal is an international, peer-reviewed open-access journal publishing original case reports from all medical specialties. Previously unpublished medical posters are also accepted relating to any area of clinical or preclinical science. Submissions should not normally exceed 2,000 words or
4 published pages including figures, diagrams and references. The manuscript management system is completely online and includes a very quick and fair peer-review system, which is all easy to use. Visit http://www.dovepress.com/testimonials.php to read real quotes from published authors.

Submit your manuscript here: https://www.dovepress.com/international-medical-case-reports-journal-journal 